DOI: https://doi.org/10.32839/2304-5809/2019-5-69-130

UDC 338.48

\author{
Yakovleva Tetiana, Bespalova Nataliia, Pecherna Kateryna
}

Alfred Nobel University

\title{
THE STATE AND PROSPECTS OF TOURISM DEVELOPMENT IN UKRAINE
}

\begin{abstract}
Summary. The present stage of development of the world economy is characterized by considerable growth rates of international trade in services and increase in a contribution of services sector to creation of GDP of the states. Among main types of services the highest indicators of development are observed in the sphere of the international tourism. Tourism is one of the most high-profitable and dynamic sectors of world economy. In many states of the world tourism develops as a system which gives all opportunities for acquaintance with history, culture, customs. Article is devoted to a problem of condition and prospects of further development of tourism in Ukraine as well as general analysis of tourist flows in the world taking into account statistics of 2017. Authors analyze the indicators of tourism industry development during recent years, defining their potential impact on the formation of tourist demand over the long term.
\end{abstract}

Keywords: tourism, tourism industry, tourist attraction, tourist destination, international tourism.

Яковлева Т.І., Беспалова Н.В., Печерна К.Ю. Університет імені Альрреда Нобеля

\section{СТАНОВИЩЕ І ПЕРСПЕКТИВИ РОЗВИТКУ ТУРИЗМУ В УКРАЇНІ}

\begin{abstract}
Анотація. Дана стадія розвитку світової економіки характеризуеться значними темпами зростання міжнародної торгівлі в послугах і збільшення внеску сфери обслуговування до створення ВВП держав. Серед головних типів послуг найвищі індикатори розвитку спостерігаються в сфері міжнародного туризму. Туризм - один з найбільш високо прибуткових і динамічних секторів світової економіки. У багатьох державах миру туризм розвивається як система, яка надає всі можливості для ознайомлення з історією, культурою, звичаями. Сфера туризму, впливає на такі ключові сектори господарства як транспорт і зв'язок, торгівлю, будівництво, сільське господарство, виробництво споживчих товарів, освіту, культуру й багато чого іншого, є каталізатором соціально-економічного розвитку країн. Не говорячи вже про те, що «годує» ця система дуже багато фізичних і юридичних осіб, так чи інакше пов'язаних з наданням туристичних послуг. Крім значної статті прибутку туризм є ще й одним з потужних факторів посилення престижу країни, росту їі значення в очах світового співтовариства й рядових громадян. Туристична діяльність у розвинених країнах є важливим джерелом підвищення добробуту держави. Високі темпи його розвитку, більші обсяги валютних надходжень активно впливають на різні сектори економіки, що сприяе формуванню власної туристської індустрії. Міжнародний туризм входить до числа трьох найбільших галузей, поступаючись нафртовидобувній промисловості й автомобілебудуванню. Значення туризму як джерела валютних надходжень, забезпечення зайнятості населення, розширення міжособистісних контактів зростає. Міжнародний туризм у світі вкрай не рівномірний, що пояснюеться в першу чергу різними рівнями соціально-економічного розвитку окремих країн і регіонів. Стаття присвячена проблемі умови і перспективам подальшого розвитку туризму в Україні, а також загального аналізу туристичних потоків в статистиці прийняття у увагу світу 2017. Автори аналізують індикатори розвитку туристичної індустрії протягом останніх років, визначаючи їх потенційний вплив на формування туристичного попиту за тривалий термін.
\end{abstract}

Ключові слова: туризм, туристична індустрія, туристична визначний пам'ятка, туристичний напрямок, міжнародний туризм.

Droblem statement. Problematics of the existing condition of tourism industry development in Ukraine and prospects of its further development have, certainly, uncommon topicality nowadays. Possibilities of potential development of tourism in an opportunity to open in Ukraine considerably bigger opportunities, than one, is one of the important tasks. Therefore, in our opinion, the subject of the present article has to be considered in a strategic context.

Problematics of definition of potential opportunities of domestic tourism development is quite up-to-date at the present stage of domestic economic science development. In particular, the subject was thoroughly and comprehensively studied by Pankova Y.In. [1], Lyubitseva O. [2], Mal's'ka M., Hudo V., Chubuk V. [3], Kifyak V. [4] and others.

Actual scientific researches and issues analysis. First of all it should be noted that according to the results of 2018 the number of international tourist arrivals in the world made 981 million people which is 46 million or $4.4 \%$ more than in 2017 and is 104 million people more than in 2009 [3; 5].

Thus, against the background of improvement of an economic situation in the world the international tourism is restored quicker, than it was expected after global financial crisis and economic downturn of the end of 2008-2009. The world tourist organization predicts that 2019 will show rates of gain of the international tourism at the level of 3-4\%. Without reckoning that it is less, than in 2010, the tourist industry of the world shows a tendency to grow. The number of the international tourist arrivals this year will reach a point of 1 billion people [3; 5].

Selection of previously unsolved parts of the whole problem. Unlike previous years, growth rates of tourism in the countries with developed economy ( $+5 \%)$ exceeded growth rates of economies which are developing $(+3.7 \%)$. This change took place mainly at the expense of high rates of Europe and as a result of problems which arose in the Middle East and in North Africa. Among 
regions the best results were achieved by Europe $(+6 \%)$, and among subregions the list is headed by South America and South Asia (+10\% each) [3; 5]. Behind absolute measures of number of the international tourist arrivals the countries of Europe continue to take the leading positions. Europe is visited by 10 times more tourists, than Africa, and 8 times more, than the Middle East). Besides that it can be observed a resistant trend of increase in a share of the developing countries in the world tourist industry and changes of the directions of world tourist flows.

Aims of the article. The present article is aimed at defining the state and prospects tourism development in Ukraine.

Achievement stated objective provides performance of the following research problems:

- to define global trends in the development of tourism;

- to characterize regional and global trends in inbound tourism;

- to analyze the influence of a political situation in regions on a condition of tourism industry;

- to define trends of internal and inbound tourism in Ukraine and the prospects of scientific researches in this industry.

Statement of basic materials. In 2017, despite economic uncertainty, the number of tourist arrivals in Europe reached 503 million people: 29 million with 41 million additional international arrivals was registered around the world. The best results showed the tourist's directions of Central, Eastern and Southern Mediterranean Europe $(+8 \%)$ each. Though partially growth of indicators of destinations of the Southern Mediterranean Europe was caused by reorientation of tourist flows which were directed to the countries of the Middle East and North Africa. Also they results were influenced by the growth of flows of tourists from Scandinavia, Germany and Russia [3;6].

In the Pacific Region ( $+5 \%)$ the number of arrivals in 2017 increased by 11 million, and the total number of the international tourist arrivals made 216 million. Southern Asia (+10\%) and South- East Asia (+9\%) achieved good results thanks to great interregional demand.

At the same time rather low growth rates were recorded by in North-East Asia (+2.5\%) and The Pacific Islands (+0.5\%) as a result temporary recession in the international tourism of Japan $[6 ; 3]$.

In the American region ( $+4 \%$ ) the number of arrivals in 2017 increased by 6 million and the general indicator was 156 million. The leading positions were reserved by South America, the number of arrivals to which increased the second year by $10 \%$. In Central America and the Caribbean Region (+4\% each) growth rates remained at the level of 2010 . North America (+3\%) in 2017 overcame a mark of 100 million tourists [3; 6].

In Africa the number of the international tourist arrivals remained at the level of 50 million as growth in arrivals in the tourist's directions of the countries to the south of the Sahara (7\%) was leveled by losses in North Africa $(-12 \%)[3 ; 6]$.

The Middle East (-8\%) where the total number of arrivals made 56 million, lost close to 5 million international tourist arrivals. Despite that, in some destinations, such as Saudi Arabia, Oman and the
United Arab Emirates, resistant growth rates remained [3; 6].

On the level of income from environments of 10 leading tourist's directions especially significant income increased in the USA (+12\%), Spain (+10\%), Hong Kong (+23\%) and Great Britain (+7\%) [5; 6].

Leaders of the expenses are the increasing guides of tourist markets: China $(+30 \%)$, Russia $(+21 \%)$, Brazil $(+32 \%)$ and India $(+33 \%)$. They are followed by the traditional markets though growth rates of expenses of tourists from Germany $(+3 \%)$ and the USA (+\%) were bigger, than in previous years $[5 ; 6]$.

The ITO predicts that economies which are developing will return themselves the leading positions on growth rates of number of the international tourist arrivals.

It can be explained, in our opinion, by several reasons. First, the political instability in the countries of the Middle East and North Africa begins to decline. The institute of studying of free time which conducts researches in the states of the European Union, defined by sociological poll that most of tourists are concerned with a problem of political stability of the state which they are ready to visit. It should be noted that this prerequisite of a successful travel occupies superiority in a significant amount of respondents, namely $74 \%$. At the same time much less tourists are concern with environmental problems in the country of travel (57\%), even less the Europeans are disturbed with danger of diseases and epidemics (55\%), natural cataclysms (49\%) and crime (44\%).

Political crisis in Egypt 2010 which is a quite popular resort among the European tourists caused mass escape of foreigners from the country. A number of ordered tours to Egypt also sharply decreased. In Germany only $50 \%$ of tourists refused to visit this country. $85 \%$ of tourists refused from visiting Tunisia where disorders began earlier. Meanwhile the tourist sector is vital for these countries. So, tourism makes up to 6\% of GDP of Egypt, and profit from tourism made 13 billion dollars in 2010. Since 2011 social disorders in the countries of the Middle East and North Africa are not dangerous any more. Therefore in 6 months of 2017 a number of the international tourist arrivals in these regions increased by $4.5 \%$ compared with an indicator of the same period of previous year. Considering the above-mentioned facts it is necessary to notice that the factor of political stability is important in tourism development, however it is difficult to be predicted. At the same time, practice of the last tourist season demonstrates that previous social disorders do not frighten off the European tourist any more, and demand for the resorts of Egypt or Tunisia can keep stability.

Secondly, it is manifestation of a global trend in shift of tourist flows. The trend which with strengthening of the European currency (euro) concerning US dollar, citizens of the United States prefer rather cheaper rest in the countries of the so-called "third world" can be observed.

Thirdly, the exotic countries of Asia and Africa today have an opportunity to offer tourists quite high level of service depending on the demands of consumers, however at the lowest prices, as attracts a considerable part of consumers of a tourist product from the USA and Europe. 
And, fourthly, together with the growth of service in hotels of the Asian and African countries, Europeans and Americans (the main consumers of a tourist product) have an opportunity to visit exotic resorts at prices quite lower than in Europe. Especially this trend amplified after crisis of 2008 when prosperities of citizens of the countries of North America and the EU were reduced. Thus, it is possible to claim that the specified trend has resistant character and it is possible to assume that demand for services of the resorts of Asia and Africa will further increase. This tendency can also be used by the countries of Eastern Europe which have sea resorts including Ukraine, however on condition of increase in level of tourist service.

Before talking about the development of tourism in Ukraine, it should be noted that accurate technique of calculation of number of tourists is absent in Ukraine. There is statistics of the State committee of statistics of Ukraine, the Ministry of infrastructure of Ukraine and State Border Guard Service of Ukraine which often sharply differ among themselves. However, based on them, trends of development of domestic tourism can be observed.

According to State Committee of Statistics of Ukraine, for 2017 with the tourist purpose Ukraine was visited by 1.083 million foreigners. Most of all tourists in 2017 arrived from Russia (165.3 thousand), Poland (143.8 thousand), Belarus (130.7 thousand), Germany (75.3 thousand), the USA (46.4 thousand), Great Britain (31.3 thousand), Italy (30.4 thousand), to Israel (25.3 thousand), France (24.3 thousand), Turkey (23.6 thousand) [7].

Though the number of foreign tourists in Ukraine in 2017, compared with previous, increased $(+19 \%)$, it did not reach the level of 2007 $2008(-10 \%)$. In general, the number of tourists foreigners in Ukraine gradually decreases, since $2004(-44 \%)$ [7] that demonstrates that against the background of growth of the international tourist traffics Ukraine gradually loses the positions which is very negative trend.

According to the Ministry of infrastructure of Ukraine, the number of tourists citizens of Ukraine who went abroad in 2017 made 1295.6 million people. This indicator is $41 \%$ more than last year's and outstripped an indicator of pre-crisis 2008 by $1 \%$, and is the highest for the last 10 years [7].

The number of internal tourists in 2017 made 649.3 thousand persons which on 444.8 thousand or are $41 \%$ less, than previous years. After splash in 2007 when over 2.1 million of internal tourists were recorded in Ukraine, their quantity gradually decreases. Instead of that on 44 thousand or for $2 \%$ the grown-up number of tourists. But it did not reach the level of 2007-2008 (-19\%) [7].

Other countries with the tourist purpose were visited by 8462 residents of the area that is $22 \%$ bigger than previous year, but is $20 \%$ less, than in 2015 . Though the number of departures of tourists abroad did not reach pre-crisis level, since 2003 the tendency to growth of interest in foreign tourism of Ukrainian residents can be is observed [8].

However the all-Ukrainian negative trend of bigger interest of Ukrainians in trips abroad than internal tourism is observed.

Its relative high cost, absence or backwardness of tourist infrastructure, weak awareness of the population and insufficient development of tourist resources of Ukraine constrain development of internal and entrance tourism in Ukraine.

Ukraine announced 2017 a year of sustainable development of tourism founded by the UN General Assembly. About 10\% of Ukrainian population work in the sphere of tourism today. Tourism crosses with the activity of 40 branches of the Ukrainian economy and enters the list of five industries of Ukraine bringing the highest income.

Last year Ukraine was visited by over 13.3 million foreign citizens that is $6.7 \%$ more, than in 2015. For the first half of the year 2017 Ukraine was visited by 6.3 million foreigners. For the same period last year our country was visited by 5.8 million foreigners.

Most of all citizens of Moldova and Belarus like to have a rest in Ukraine. This year Ukrainian cities have been visited by 2 million Moldovans and more than 1 million Belarusians. Hungarians and Poles also come to have a rest here. In 2017 Ukraine was visited by 620 thousand Russians which is $4 \%$ more than the previous year, despite an image of the enemy which Russian government forms among Russian population in relation to our country. Inflow of citizens from Israel and Turkey (215 thousand people) has increased by $30 \%$. Residents of Belgium and Switzerland have also got interested in Ukraine recently.

Ukrainians' living standards as well as income declining resulted in the development of internal tourism whish has become really popular. The popularity of internal tourism destinations has grown tenfold. Statistics shows that last year the number of internal tourists in Ukraine was over 453.500 people. Climatic and geographical conditions of our country allow developing different types of travel business.

The Azov and Black Sea Riviera.

There is a great number of beach resorts In Ukraine. Despite loss of the Crimea, Ukraine has numerous popular beach resorts on the Black Sea shore - Koblevo and Zatoka. The resort of Koblevo is located on the territory of Nikolaev region in a pinery on the Black Sea coast. Koblevo is appreciated by its wide sandy beaches and well developed infrastructure. On the territory of this resort there are tens of hotels, recreation houses and centers of economy and premium class which can accept 17 thousand vacationers at the same time. The resort season in Koblevo starts in May and comes to an end in September. The cost of residence in Koblevo fluctuates from 500 to $1100 \mathrm{UAH}$, and the cost of three meals a day is $200 \mathrm{UAH}$.

Populated locality Zatoka in Odessa region which has reputation of the noisiest and youth resort in Ukraine is not less popular. There are a lot of different night clubs, water and extreme amusement rides. The cost of accommodation in this resort is lower, than in Koblevo. In the private sector it is possible to find a bed from 130 to $150 \mathrm{UAH}$ a day, in recreation houses and centers - 210-260 UAH, in mini-hotels - 300-500 UAH. Three meals a day costs from 200 UAH a day. Disadvantages of Zatoka region are frequent storms in this area, strong currents which bring cold water and also proximity of the route Odessa-Reni as well as railway roads.

Also sea resorts exist in other settlements of Odessa region - in Primorsk, Lebedevke, Karoli- 
no-Bugaz, Gribovke and even in the industrial city of Yuzhnyi.

Sea resorts exist on the coast of the Sea of Azov, including Genichesk in the Kherson region, Berdyansk in the Zaporozhye region, boarding houses and recreation facilities near Mariupol (Donetsk region).

To receive medical treatment and have a rest in health resorts Ukrainians go to Truskavets, Morshin, Skhodnitsa and the resorts of Zakarpattia. Green or agrarian tourism has become a trend nowadays. Residents of large cities go to rural areas where they can not only breathe fresh air, but also live country life, get acquainted with traditions and culture, national crafts and crafts of original regions of Ukraine.

"Green" tourists work in the field, gather mushrooms in the forest, ride horses, go fishing, hunt and thus have a rest far away from office or factory everyday life. There are over 20 large estates of green tourism in Ukraine: in Poltava region, Ivano-Frankivsk region, Vinnytsia region, Zakarpattia region, Cherkassk region and Kiev region.

Excursion all over the territory of Ukraine are organised and held all the year round. Cities such as Kiev, Lviv, Chernivtsi, Baturin, Odessa, Uzhhorod, Kharkiv, island of Hortitsa in Zaporizhia which are abound with cultural and historical monuments are especially popular among tourists. The most popular city among tourists is Kiev. Last year the capital was visited by over 1 million 200 thousand foreign tourists and 2 million internal tourists.
Conclusions and prospects. The results of international tourism development in the world and in Ukraine have been analyzed. Recommendations on the perfection of management by tourist enterprises have been justified taking into account modern tendencies in the market of tourist services. The results of international tourism development have been analyzed. Basic leading countries providing international tourist services have been identified, basic performance indicators of Ukraine's tourist enterprises have been presented, Ukraine's regions getting the highest profits from the tourist activity have been identified. A basic tendency in international tourism has been revealed which is internationalization and concentration of capital, that influences personnel competences of tourist enterprises. A system of continuous training is offered for managers of international tourism, who must possess both special and universal professional competences.

Prerequisite for further development of national tourism in compliance with trends of the world tourist market is: application of international legislative and regulatory framework of tourism, development of quality standards of tourist service; development of progressive technologies with the sphere of tourist activity; introduction of the advanced systems and methods of preparation and professional development of tourist shots; use of opportunities of world information space, scientific researches, experience of state regulation and stimulation of field of tourism, practice creations of organizational and financial bases of functioning of highly profitable tourist industry.

\section{References:}

1. Pankova Ye.V. (2007). Turystychne kraieznavstvo : navchalnyi posibnyk [Tourist study of local lore : manual]. Kyiv : Alterpres, $352 \mathrm{p}$.

2. Liubitseva O.O. (2003). Metodyka rozrobky turiv : navchalnyi posibnyk [Technique of tours development: manual]. Kyiv : Alterpres, 104 p.; Liubitseva O.O. (2002). Rynok turystychnykh posluh [Market of tourist services]. Kyiv : Alterpres, $436 \mathrm{p}$.

3. Malska M.P., Khudo V.V., Tsybukh V.I. (2004). Osnovy turystychnoho biznesu : navch. posibnyk [Basis of travel business : manual]. Kyiv : Tsentr navchalnoi literatury, $272 \mathrm{p}$.

4. Kyfiak V.F. (2003). Orhanizatsiia turystychnoi diialnosti v Ukraini [Organization of tourist activity in Ukraine]. Chernivtsi : Knyhy-XXI, 300 p.

5. UNWTO World Tourism Barometer. Vol. 10. January 2012. Statistical Annex.

6. UNWTO World Tourism Barometer. Vol. 10. January 2012.

7. Derzhavna sluzhba statystyky Ukrainy. URL: http://www.ukrstat.gov.ua

8. Holovne upravlinnia statystyky u Cherkaskii oblasti. URL: http://www.ck.ukrstat.gov.ua/?p=stat_inform

9. Sushko N.V. (2010). Istorychni mistsia ta rozvytok turyzmu na Cherkashchyni (1990 rr. KhKh st. - pochatok XXI st.) [Historical places and development of tourism in Cherkasshchina (1990 of the 20th century the beginning of the 21st century)] : avtoreferat dysertatsii na zdobuttia naukovoho stupenia kandydata istorychnykh nauk. Cherkasy, $20 \mathrm{p}$. 